\title{
NEW RECORDS OF THE GOATFISH, UPENEUS VITTATUS (FORSSKAL 1775) AND UPENEUS SUPRAVITTATUS (UIBLEIN AND HEEMSTRA 2010) (PRECIFORMES, MULLIDAE), FROM SAINT MARTIN'S ISLAND IN THE BAY OF BENGAL, BANGLADESH
}

\author{
SHILPI SAHA ${ }^{1}$, SUBRINA SEHRIN ${ }^{1}$, ABDULLAH-AL-MASUD ${ }^{1}$, KAZI AHSAN HABIB ${ }^{2}$, \\ ANIRB AN SARKER ${ }^{1}$, MOHAMMAD ABDUL BAKI ${ }^{* 1}$ \\ ${ }^{1}$ Department of Zoology, Jagannath University, Dhaka-1100, Bangladesh \\ ${ }^{2}$ Department of Fisheries, Sher-e-Bangla Agricultural University, Dhaka-1207, Bangladesh
}

\begin{abstract}
Genus Upeneus distributed in Indo-Pacific, South Africa, north to southern Japan and south to New Caledonia. Although there is difficulty in identifying accurately goatfish solely on the basis of morphology, $U$. vittatus and $U$. supravittatus were confirmed by both using morphological characters and DNA barcoding cytochrome oxidase I subunit (COI) approach for the first time in St. Martin's Island, Bay of Bengal, Bangladesh. Increased number of species of the genus Upeneus was found in Bangladesh from 3 to 5 and extended the distribution range.
\end{abstract}

Key words: Coral ecosystem, Cytochrome oxidase I subunit (COI), Morphomeristics, New record, Upeneus vittatus, $U$. supravittatus

\section{Introduction}

The goatfishes (Perciformes: Mullidae) are characterized by a pair of long barbels at the front of the chin, two well-separated dorsal fins with 7 or 8 spines and a deeply forked caudal fin. The family Mullidae consisted of 6 genera that are differentiated mainly by dentition as shown in the key of Lachner in Schultz and collaborators (1960). Species of Upeneus are only ones with teeth in both jaws and on the vomer and palatines. There are 29 species of the genus Upeneus (Uiblein and Heemstra 2011, Yamashita et al. 2011) found in shallow coastal waters above $100 \mathrm{~m}$. The yellow striped goatfish, Upeneus vittatus (Kuiter and Tonozuka 2001) is a marine, brackish, coral reef associated fish species. Sandy lagoons, sheltered coastal waters and also muddy bottoms (Fischer et al. 1990) are preferred habitats of $U$. vittatus. This species is euryhaline (Lewis and Pring 1986), benthopelagic (Mundy 2005) often found in groups (Lieske and Myers 1994) and feeds primarily on small crustaceans (Sousa and Dias 1981). The long fin goatfish, U. supravittatus (Uiblein and Heemstra 2010) is a marine, coral reef associated fish species. They use their two sensitive chin barbels to dig into the sediment to locate food items. Invertebrates such as small crustaceans and worms are hunted by small goatfish that forage on the bottom in loose schools. In contrast, large individuals ( $20-40 \mathrm{~cm}$ in length) also feed on small fishes (Sea-Ex). At present, only three species of this genus, U. sulphureus (Tomascik 1997), U. sundaicus and $U$. tragula (Rahman et al. 2009) have been recorded in Bangladesh and studied

\footnotetext{
*Author for correspondence: <mabaki@gmail.com>.
} 
only on the basis of morphological characters. However, specimens of Upeneus are often difficult to identify to species, as a promising alternative to the traditional species identification based on morphological characters, partial cytochrome $\mathrm{c}$ oxidase subunit I (COI) sequences (DNA barcodes) have been suggested for standardized and routine species identification (Hebert et al. 2003). Newly generated DNA barcodes can be analyzed together with available data (shown in bold face overleaf) to resolve taxonomic conflicts. Although barcodes for almost one-third $(10,267)$ of all described fish species are already available (Ward 2012), the permanent addition of new barcode data is indispensable to increase the taxonomic resolution. The present study to identify $U$. vittatus and $U$. supravittatus was based on morphomeristics as well as DNA barcoding for the first time in Bangladesh, and distinguished from each other and also from other Upeneus spp. recorded before in Bangladesh.

\section{Materials and Methods}

Sample collection: Fish specimens were collected on 14 December, 2015 from local fishermen of St. Martin's Island (Fig. 1) $\left(20^{\circ} 34^{\prime} \mathrm{N}-20^{\circ} 38.8^{\prime} \mathrm{N}\right.$ and $92^{\circ} 18^{\prime} \mathrm{E}-$ $\left.92^{\circ} 20.8^{\prime} \mathrm{E}\right)$ who collected these fishes using gear named ber jal which is one kind of seine net and not destructive. Specimens were collected in full accordance with local government regulation, and in compliance with appropriate animal care standards. After that specimens were carried with cooling box to $-20^{\circ} \mathrm{C}$ in Fisheries laboratory, Department of Zoology, Jagannath University, Dhaka until further study. After study, all specimens were deposited in the museum of Zoology Department, Jagannath University as voucher specimen with registration number Upeneus vittatusF1215SM02 and Upeneus supravittatus-F1215SM03.

Morphological studies: Morphometric and meristic characters were compared with previous records by Uiblein and Heemstra (2010) from Western Indian Ocean and other 3 species of Upeneus already recorded from Bangladesh water. Lengths were measured in $\mathrm{cm}$ scale and weight in gm. The meristic abbreviations used in this study are as follows: $\mathrm{D}_{1}$, first dorsal fin; $\mathrm{D}_{2}$, second dorsal fin; $\mathrm{P}$, pectoral fin; V, pelvic fin; A, anal fin; $\mathrm{C}$, caudal fin; $\mathrm{Li}$, lateral-line scale; aLi, transverse scale above lateral-line; bLi, transverse scale below lateral-line; $\mathrm{Br}$, branchiostegal ray. Detailed morphomeristics study was carried out.

Molecular phylogenetic studies: Intra- and inter-specific genetic distances were determined using a molecular marker cytochrome oxidase subunit I (COI) gene of mitochondrial DNA. Muscle tissue was isolated from just below the dorsal fin. DNA was extracted by TIANamp Marine Animal DNA Kit. Approximately 700 bp were amplified from the 5' region of the COI gene using C FishF1t1/C FishR1t1 primer cocktails (Ivanova et al. 2007) due to its high effectiveness in generating amplicons that sequence cleanly for the DNA barcode region of diverse fish taxa and other groups of vertebrate. There are two primers (FishF2 t1/VF2 t1) for cocktail C FishF1t1 and 
also two primers (FishR2 t1/FR1d t1) for C FishR1t1. To facilitate sequencing of products, all PCR primers were tailed with M13 sequences. The primer's nucleotide sequences were:

\section{VF2_t1-5'-*TGTAAAACGACGGCCAGTCAACCAACCACAAAGACATTGGCC -3' \\ FishF2_t1-5'-*TGTAAAACGACGGCCAGTCGACTAATCATAAAGATATCGGCAC-3' FishR2_t1-5'-*CAGGAAACAGCTATGACACTTCAGGGTGACCGAAGAATCAGA-3' FR1d_t1-5'-*CAGGAAACAGCTATGACACCTCAGGGTGTCCGAARAAYCARAA-3'}

[*The M13 primer sequence in bold face]

The PCR reactions were carried out in $20 \mu \mathrm{l}$ reaction mixture containing $6.0 \mu \mathrm{l}$ of distilled water, $10 \mu \mathrm{l}$ of master mix, $1 \mu \mathrm{l}$ of each primer $(5 \mu \mathrm{mol} / \mathrm{l})$ and $2 \mu \mathrm{l}$ of DNA template. The thermal regime consisted of an initial step of $2 \mathrm{~min}$ at $94^{\circ} \mathrm{C}$ followed by 35 cycles of $30 \mathrm{sec}$ at $94^{\circ} \mathrm{C}, 40 \mathrm{sec}$ at $52^{\circ} \mathrm{C}$, and $1 \mathrm{~min}$ at $72^{\circ} \mathrm{C}$, followed in turn by 10 min at $72^{\circ} \mathrm{C}$. Then soak at $4^{\circ} \mathrm{C}$. PCR products were purified by using QIAquick PCR purification kit. After purification, the products were sequenced in both directions by using commercial sequencer, Macrogen, Korea. Sequences were manually edited using the software Chromas Lite. For phylogenetic analysis, COI sequences of same species and species in the same genus were downloaded from GenBank. The species and their GenBank accession numbers are following: KX024776 for U. vittatus; KR057896 for U. supravittatus; KP293705, KP293708 for U. suahelicus; EF607613, EF607614 for U. tragula; JN313348 for U. sulphureus and FJ237883 for Parupeneus indicus. The software MEGA 6 (Tamura et al. 2013) was used for alignment and construction of neighbor-joining tree (Saitou and Nei 1987) on the basis of evolutionary distances calculated using the Kimura two parameter (K2P) model (Kimura 1980), where bootstrapping replications were 1000. Molecular phylogenetic analysis was conducted in the Aquatic Biodiversity Research Laboratory, Department of Fisheries, Sher- eBangla Agricultural University, Dhaka-1207, Bangladesh.

\section{Results and Discussion \\ Upeneus vittatus (Forsskal 1775)}

Identification: The morphometric measurements of this species are provided in Table 1 and meristics in Table 2. Body elongated, laterally compressed, dorsal profile convex slightly and moderate in size. Head medium and obtuse. Large, rounded, highly protractile, superior mouth placed sub-terminally with large mouth gap. Unequal jaws with cardiform teeth, also present on palatine and vomer. Two barbels present on chin.

Large operculum with flap and large opercular opening. Lateral line is single, complete and curved. Scales are ctenoid, rhomboidal, large and overlapping. Dorsal fin double, separate, medium and situated at the middle of the body, which starts from the middle of pectoral fin and reaches up to the just opposite to end of anal fin, having spines in front. Pectoral fin large, wide spread and placed ventro-laterally. Pelvic fin moderate in 
size and present at the forward. Anal fin medium, contains spines in front and reaches up to the opposite of $2^{\text {nd }}$ dorsal fin. Caudal fin forked and homocercal type.

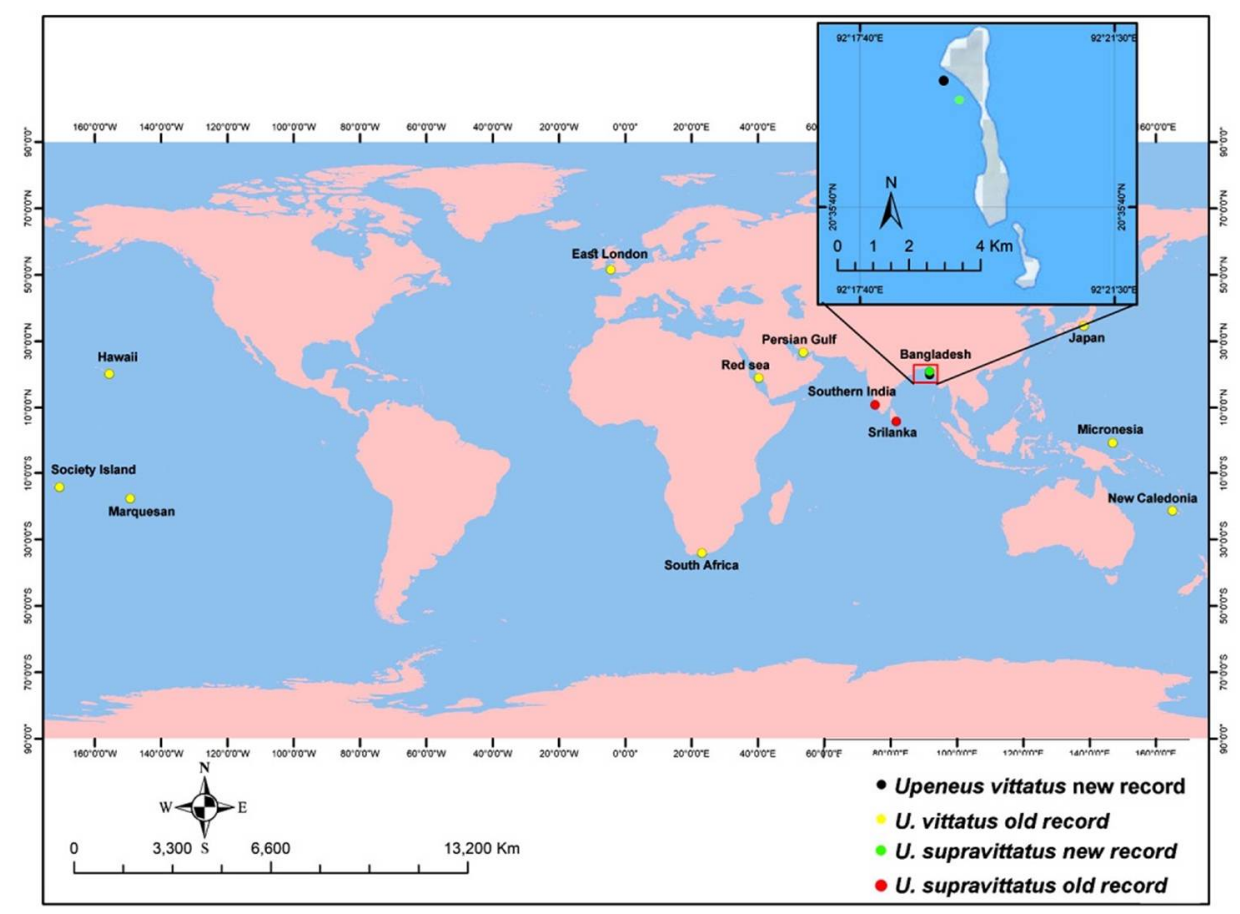

Fig. 1. Location of new and old record of Upeneus vittatus and $U$. supravittatus species in the St. Martin's Island, Bay of Bengal, Bangladesh.

Coloration: Body reddish dorsally, silver ventrally in fresh fish. Four golden stripespresent, among them 2 mid lateral, one starts from eye and extends up to base of caudal fin, attaches the adjacent bar of upper caudal fin lobe and the other stripe starts from below of pectoral fin base and extends up to caudal peduncle and joined by adjacent bar of lower caudal fin lobe; 2 dorsolateral stripes, where lower one well defined, starts from operculum and extends up to behind of second dorsal fin, the upper one ambiguous and much shorter, starts from below of first dorsal fin origin and surrounded dorsally by a horizontal series of pale spots (Fig. 2a). Two yellow stripes present on white membrane in both dorsal fin and a broad black spot on the tip of $1^{\text {st }}$ dorsal fin anteriorly, the straight length of the black spot similar in size to broadness of broadest lower caudal fin lobe bar (Fig. 2c); reddish pectoral, brown pelvic, reddish anal fin and yellowish patches along pelvic and anal fin bases; five yellow black oblique bars on upper lobe of caudal fin and 3 on lower (Fig. 2e) those increasing 
distally in width with the widest distal-most bar black or dark brown, while the other bars are yellow blackish; broadness of broadest lower caudal fin lobe bar and/or light colored gap between bars that are most distally located equal to or larger than eye diameter; light colored tip of lower fin lobe. Barbels are white.
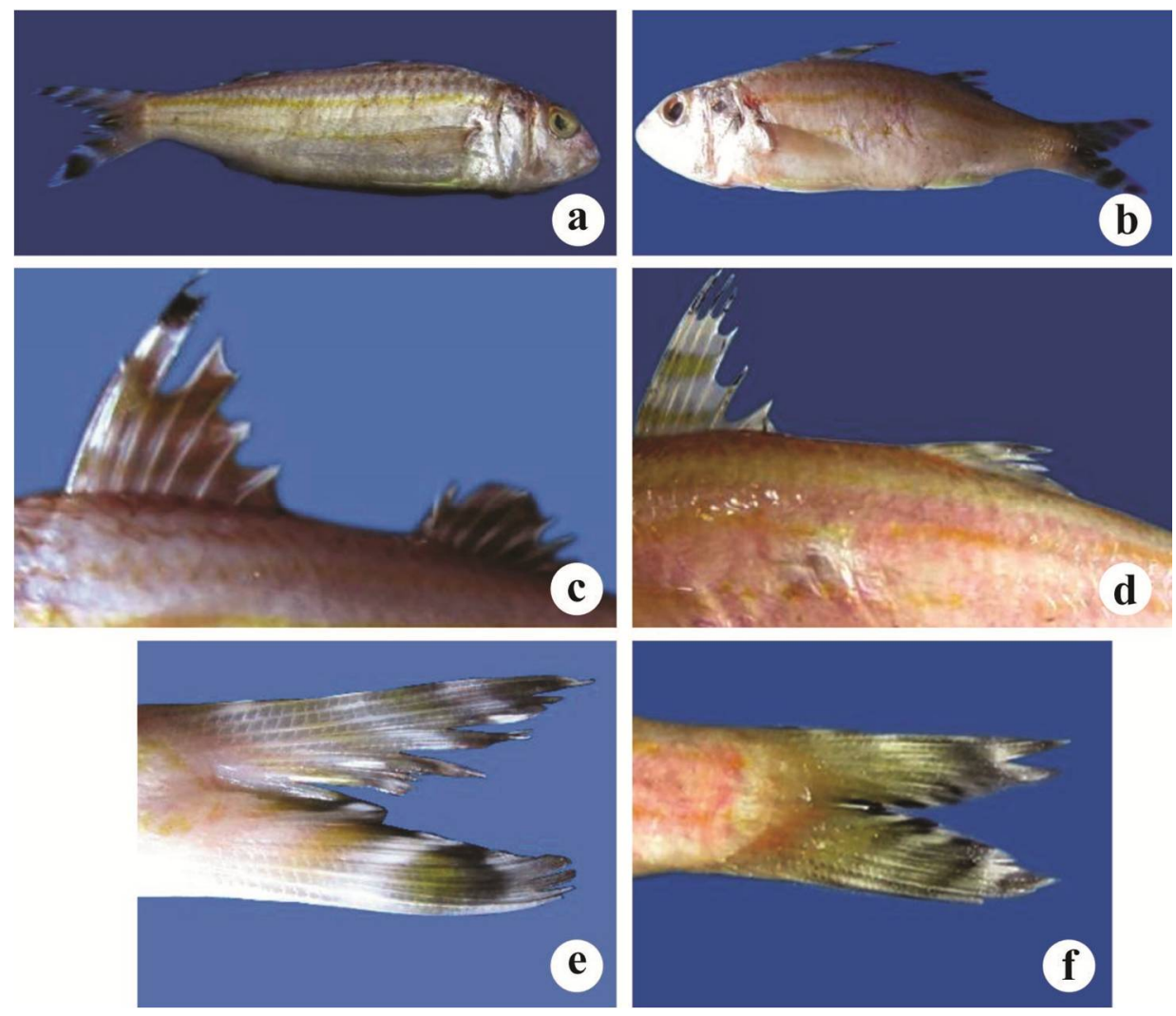

Fig. 2. (a) Upeneus vittatus (10.6 cm SL), (b) Upeneus supravittatus $(11.1 \mathrm{~cm} \mathrm{SL})$, (c) dorsal fin of Upeneus vittatus, (d) dorsal fin Upeneus supravittatus, (e) caudal fin of Upeneus vittatus and (f) caudal fin of Upeneus supravittatus.

\section{Upeneus supravittatus (Uiblein and Heemstra 2010)}

Identification: The morphometric measurements of this species are provided in Table 3 and meristics in Table 4. Body elongated, laterally compressed, dorsal profile convex slightly and moderate in size. Head medium and obtuse. Large, rounded, highly protractile, superior mouth placed sub-terminally with large mouth gap. Unequal jaws with cardiform teeth, also present on palatine and vomer. Two barbels present on chin. Large operculum with flap and large opercular opening. Lateral line single, complete 
and curved. Scales are ctenoid, rhomboidal, large and overlapping. Dorsal fin double, separate, medium and situated at the middle of the body, which starts from the middle of pectoral fin and reaches upto the just opposite to end of anal fin, having spines in front. Pectoral fin large, wide spread and placed ventro-laterally. Pelvic fin moderate in size and present at the forward. Anal fin medium, contains spines in front and reaches upto the opposite of $2^{\text {nd }}$ dorsal fin. Caudal fin forked and heterocercal, lower lobe slightly shorter than upper.

Table 1. Morphometric measurements of Upeneus vittatus from Bangladesh and comparative materials reported from other places.

\begin{tabular}{|c|c|c|c|c|c|}
\hline Characteristics & $\begin{array}{l}\text { Measurements } \\
\text { (Present } \\
\text { study) }\end{array}$ & $\begin{array}{l}\text { Uiblein and } \\
\text { Heemstra } \\
\text { (2010) }\end{array}$ & Characteristics & $\begin{array}{l}\text { Measurements } \\
\text { (Present study) }\end{array}$ & $\begin{array}{c}\text { Uiblein } \\
\text { and } \\
\text { Heemstra } \\
(2010)\end{array}$ \\
\hline \multicolumn{6}{|c|}{ Percentage of standard length } \\
\hline Head length & 35.85 & - & Longest anal spine & $10.38\left(1^{\mathrm{st}}\right)$ & - \\
\hline Body depth & 29.25 & - & $\begin{array}{l}\text { Longest anal fin } \\
\text { ray length }\end{array}$ & 16.98 & $15-16$ \\
\hline Body width & 17.92 & - & $\begin{array}{l}\text { Pectoral fin base } \\
\text { length }\end{array}$ & 5.66 & - \\
\hline $\begin{array}{l}\text { Caudal peduncle } \\
\text { depth }\end{array}$ & 9.43 & - & $\begin{array}{l}\text { Longest pectoral } \\
\text { fin ray length }\end{array}$ & 25.47 & $22-24$ \\
\hline $\begin{array}{l}\text { Caudal peduncle } \\
\text { length }\end{array}$ & 18.87 & - & $\begin{array}{l}\text { Pelvic fin base } \\
\text { length }\end{array}$ & 4.71 & - \\
\hline Caudal concavity & 20.75 & - & $\begin{array}{l}\text { Longest pelvic fin } \\
\text { ray length }\end{array}$ & 19.81 & $18-21$ \\
\hline $\begin{array}{l}\text { Caudal fin base } \\
\text { length }\end{array}$ & 12.26 & - & Barbel length & 19.81 & $17-21$ \\
\hline Predorsal length & 44.34 & - & Inter-orbital length & 9.43 & - \\
\hline Preanal length & 73.58 & - & Preorbital length & 12.26 & - \\
\hline Prepectoral length & 44.34 & - & Post-orbital length & 14.15 & - \\
\hline Prepelvic length & 37.74 & - & Eye diameter & 9.43 & $7.0-8.7$ \\
\hline First dorsal fin height & 23.5 & $22-25$ & Snout length & 7.56 & - \\
\hline $\begin{array}{l}\text { Dorsal fin base } \\
\text { length }\left(1^{\text {st }}\right)\end{array}$ & 21.70 & - & Upper jaw length & 14.15 & $11-13$ \\
\hline $\begin{array}{l}\text { Dorsal fin base } \\
\text { length }\left(2^{\text {nd }}\right)\end{array}$ & 14.15 & - & Lower jaw length & 9.43 & - \\
\hline Longest dorsal spine & $23.58\left(1^{\mathrm{st}}\right)$ & - & Jaw gap & 15.09 & - \\
\hline Anal fin base length & 12.26 & - & & & \\
\hline
\end{tabular}


New records of the goatfish

Table 2. Meristic features of Upeneus vittatus and comparative materials reported from other places.

\begin{tabular}{ccccccc}
\hline Characteristics & $\begin{array}{c}\text { Present } \\
\text { study }\end{array}$ & $\begin{array}{c}\text { Uiblein and } \\
\text { Heemstra } \\
(2010)\end{array}$ & $\begin{array}{c}\text { Kuiter and } \\
\text { Tonozuka } \\
(2001)\end{array}$ & $\begin{array}{c}\text { FAO } \\
(1983 \mathrm{a})\end{array}$ & $\begin{array}{c}\text { FAO } \\
(1983 \mathrm{~b})\end{array}$ & $\begin{array}{c}\text { FAO } \\
(1983 \mathrm{c})\end{array}$ \\
\hline $\mathrm{D}_{1}$ & $\mathrm{VII}$ & - & VIII & VII-VIII & - & - \\
$\mathrm{D}_{2}$ & $\mathrm{I} / 8 \mathrm{br}$ & - & - & $\mathrm{I} / 9 \mathrm{br}$ & - & - \\
$\mathrm{P}$ & 14 & - & - & 13 to 17 & - & - \\
$\mathrm{V}$ & $\mathrm{I} / 5 \mathrm{br}$ & - & - & I/5 & - & - \\
$\mathrm{A}$ & $\mathrm{I} / 6 \mathrm{br}$ & - & - & - & - & $13 \mathrm{br}$ \\
$\mathrm{C}$ & $13 \mathrm{br}$ & - & - & - & - & - \\
$\mathrm{L}$ & 37 & $36-38$ & - & - & - & - \\
$\mathrm{aLi}$ & 2 & - & - & - & - & - \\
$\mathrm{bLi}$ & 6 & - & - & - & - \\
$\mathrm{Br}$ & $2 \mathrm{pair}$ & & - & - & - & - \\
\hline
\end{tabular}

Table 3. Morphometric measurements of Upeneus supravittatus from Bangladesh and comparative materials reported from other places.

\begin{tabular}{|c|c|c|c|c|c|}
\hline Characteristics & $\begin{array}{c}\text { Measurements } \\
\text { (Present } \\
\text { study) }\end{array}$ & $\begin{array}{c}\text { Uiblein and } \\
\text { Heemstra } \\
(2010)\end{array}$ & Characteristics & $\begin{array}{c}\text { Measurements } \\
\text { (Present } \\
\text { study) }\end{array}$ & $\begin{array}{c}\text { Uiblein and } \\
\text { Heemstra } \\
(2010)\end{array}$ \\
\hline \multicolumn{6}{|c|}{ Percentage of standard length } \\
\hline Head length & 33.33 & $30-33$ & $\begin{array}{l}\text { Anal fin base } \\
\text { length }\end{array}$ & 11.71 & - \\
\hline Body depth & 27.93 & $26-29$ & $\begin{array}{l}\text { Longest anal fin } \\
\text { ray length }\end{array}$ & 15.32 & $14-17$ \\
\hline Body width & 16.22 & - & $\begin{array}{l}\text { Pectoral fin base } \\
\text { length }\end{array}$ & 6.31 & - \\
\hline $\begin{array}{l}\text { Caudal peduncle } \\
\text { depth }\end{array}$ & 10.81 & $9.9-11$ & $\begin{array}{l}\text { Longest pectoral } \\
\text { fin ray length }\end{array}$ & 26.13 & $25-28$ \\
\hline $\begin{array}{l}\text { Caudal peduncle } \\
\text { length }\end{array}$ & 19.82 & - & $\begin{array}{l}\text { Pelvic fin base } \\
\text { length }\end{array}$ & 5.41 & - \\
\hline $\begin{array}{l}\text { Caudal } \\
\text { concavity }\end{array}$ & 13.51 & - & $\begin{array}{l}\text { Longest pelvic fin } \\
\text { ray length }\end{array}$ & 19.82 & $18-21$ \\
\hline $\begin{array}{l}\text { Caudal fin base } \\
\text { length }\end{array}$ & 11.71 & - & Barbel length & 19.82 & $19-23$ \\
\hline Predorsal length & 42.34 & - & Interorbital length & 9.0 & - \\
\hline Preanal length & 72.07 & - & Preorbital length & 11.71 & - \\
\hline $\begin{array}{l}\text { Prepectoral } \\
\text { length }\end{array}$ & 34.23 & - & Postorbital length & 13.51 & - \\
\hline Prepelvic length & 36.04 & - & Eye diameter & 8.12 & $6.8-8.5$ \\
\hline $\begin{array}{l}\text { First dorsal fin } \\
\text { height }\end{array}$ & 26.1 & $23-26$ & Snout length & 6.31 & - \\
\hline $\begin{array}{l}\text { Dorsal fin base } \\
\text { length }\left(1^{\text {st }}\right)\end{array}$ & 17.12 & - & Upper jaw length & 12.61 & $12-14$ \\
\hline $\begin{array}{l}\text { Dorsal fin base } \\
\text { length }\left(2^{\text {nd }}\right)\end{array}$ & 14.41 & - & Lower jaw length & 12.61 & - \\
\hline $\begin{array}{l}\text { Longest dorsal } \\
\text { spine }\end{array}$ & $26.13\left(2^{\text {nd }}\right)$ & - & Jaw gap & 9.0 & - \\
\hline
\end{tabular}


Table 4. Meristic features of Upeneus supravittatus and comparative materials reported from other places.

\begin{tabular}{llcclcc}
\hline Characteristics & $\begin{array}{c}\text { Present } \\
\text { study }\end{array}$ & $\begin{array}{c}\text { Uiblein and } \\
\text { Heemstra } \\
(2010)\end{array}$ & $\begin{array}{c}\text { Kuiter and } \\
\text { Tonozuka } \\
(2001)\end{array}$ & $\begin{array}{c}\text { FAO } \\
(1983 \mathrm{a})\end{array}$ & $\begin{array}{c}\text { FAO } \\
(1983 \mathrm{~b})\end{array}$ & $\begin{array}{c}\text { FAO } \\
(1983 \mathrm{c})\end{array}$ \\
\hline $\mathrm{D}_{1}$ & $\mathrm{VII}$ & - & VIII & VII-VIII & - & - \\
$\mathrm{D}_{2}$ & $\mathrm{I} / 8 \mathrm{br}$ & - & - & $\mathrm{I} / 9 \mathrm{br}$ & - & - \\
$\mathrm{P}$ & 14 & - & - & 16 to 17 & - & - \\
$\mathrm{V}$ & $\mathrm{I} / 5 \mathrm{br}$ & - & - & $\mathrm{I} / 5$ & - & - \\
$\mathrm{A}$ & $\mathrm{I} / 6 \mathrm{br}$ & - & - & - & $\mathrm{I} / 6-7$ & - \\
$\mathrm{C}$ & $17 \mathrm{br}$ & - & - & - & - & $13 \mathrm{br}$ \\
$\mathrm{L}_{\mathrm{i}}$ & 35 & $34-36$ & - & - & - & - \\
$\mathrm{aLi}$ & 2 & - & - & - & - & - \\
$\mathrm{bLi}$ & 6 & - & - & - & - & - \\
$\mathrm{Br}$ & 2 pair & - & - & - & - & - \\
\hline
\end{tabular}

Coloration: Body reddish dorsally, silver ventrally in fresh fish which become pale after preservation. Two yellow stripes present on body (Fig. 2b), one starts from behind head and extends up to base of caudal fin, attaches the adjacent bar of upper caudal fin lobe and the other stripe starts from below of pectoral fin base and extends up to caudal peduncle and joined by adjacent bar of lower caudal fin lobe. In both dorsal fin 2 yellow stripes present on white membrane and the tip of first dorsal fin black (Fig. 2d). Reddish pectoral, brown pelvic, reddish anal fin and yellowish patches along pelvic and anal-fin bases; total 9 bars on caudal fin, 5 yellow blackish bars on upper caudalfin lobe, 4 bars on lower lobe, increasing distally in width (Fig. 2f). Barbels are white.

Although $U$. vittatus and $U$. supravittatus at a glance are very similar but have distinct morphological difference and also clearly different from other three Upeneus spp. such as $U$. sulphureus, $U$. sundaicus and $U$. tragula which were recorded before in Bangladesh. So, comparative morphological difference among these five Upeneus spp. are summarized in Table 5.

Sequence analysis of the COI gene: COI gene fragments of single U. vittatus and $U$. supravittatus individual were amplified. Both the COI sequences were submitted to GenBank with the following accession numbers: MG099705 for U. vittatus and MG196640 for $U$. supravittatus. Including the eight downloaded COI sequences of family Mullidae, totally ten sequences were used in the analysis and their accession number with sampling location were shown in the associated figure. COI sequences of $U$. vittatus and $U$. supravittatus showed $100 \%$ similarity with COI sequences of the respected species in NCBI (https://blast.ncbi.nlm.nih.gov/Blast.cgi). The mean interspecies evolutionary divergence was $0.2-16.3 \%$ between $U$. vittatus and other five species of family Mullidae while $0.2-16.1 \%$ between $U$. supravittatus and other five species of family Mullidae (Table 6). 
Table 5. Comparison of $U$. vittatus and $U$. supravittatus and 3 other species of Upeneus previously recorded from Bangladesh.

\begin{tabular}{|c|c|c|c|c|c|}
\hline & U. vittatus ${ }^{\mathrm{a}, \mathrm{b}}$ & U. supravittatus ${ }^{\mathrm{a}, \mathrm{b}}$ & U. sulphureus ${ }^{\mathrm{a}, \mathrm{b}}$ & U. sundaicus $\mathrm{s}^{\mathrm{a}, \mathrm{b}}$ & U. tragula, \\
\hline Body stripe & 4 golden & 2 yellow & 2 yellow & 1broad yellow & 1 broad black \\
\hline Body color & $\begin{array}{l}\text { Reddish } \\
\text { dorsally, silver } \\
\text { ventrally }\end{array}$ & $\begin{array}{l}\text { Reddish dorsally, } \\
\text { silver ventrally }\end{array}$ & $\begin{array}{l}\text { Pale brown } \\
\text { dorsally, white } \\
\text { ventrally }\end{array}$ & $\begin{array}{l}\text { Light reddish } \\
\text { dorsally, white } \\
\text { ventrally with } \\
\text { yellow-green } \\
\text { ventral margin }\end{array}$ & $\begin{array}{l}\text { Light greenish } \\
\text { dorsally, } \\
\text { whitish } \\
\text { ventrally }\end{array}$ \\
\hline $\begin{array}{l}\text { Spot, stripeor } \\
\text { patch on } \\
\text { dorsal fin }\end{array}$ & $\begin{array}{l}\text { Broad black } \\
\text { spot on the tip } \\
\text { of } 1^{\text {st }} \text { dorsal fin }\end{array}$ & Absent & $\begin{array}{l}1^{\text {st }} \text { dorsal fin tip } \\
\text { black }\end{array}$ & 3 red stripes & $\begin{array}{l}2 \text { black and } 2 \\
\text { white patches } \\
\text { present } \\
\text { alternately }\end{array}$ \\
\hline $\begin{array}{l}\text { Bar on caudal } \\
\text { fin }\end{array}$ & $\begin{array}{l}5 \text { yellow black } \\
\text { oblique bars on } \\
\text { upper lobe and } \\
3 \text { on lower }\end{array}$ & $\begin{array}{l}5 \text { black oblique } \\
\text { bars on upper lobe } \\
\text { and } 4 \text { on lower }\end{array}$ & No bar & $\begin{array}{l}5 \text { red bars on } \\
\text { upper lobe and no } \\
\text { bar on lower lobe }\end{array}$ & $\begin{array}{l}4 \text { blackish } \\
\text { oblique bars on } \\
\text { upper lobe and } \\
5 \text { on lower }\end{array}$ \\
\hline $\begin{array}{l}\text { Lateral line } \\
\text { scales }\end{array}$ & 37 (36-38) & $35(34-36)$ & $34(34-37)$ & $34(31-34)$ & $31(28-31)$ \\
\hline $\begin{array}{l}\text { Scales } \\
\text { above/below } \\
\text { lateral line }\end{array}$ & $2 / 6$ & $2 / 6$ & $2 / 4$ & $3 / 5$ & $3 / 5$ \\
\hline
\end{tabular}

${ }^{\mathrm{a} P r e s e n t}$ study; ${ }^{\mathrm{b}}$ Uiblein and Heemstra (2010) and reference values are shown in parentheses.

The construction of Neighbor-joining tree was done on the basis of K2P model, where replications of bootstrapping test was 1000 . In the phylogenetic tree (Fig. 3) U. vittatus and $U$. supravittatus clustering together and they are apparently also very similar but with distinct difference in morphology.

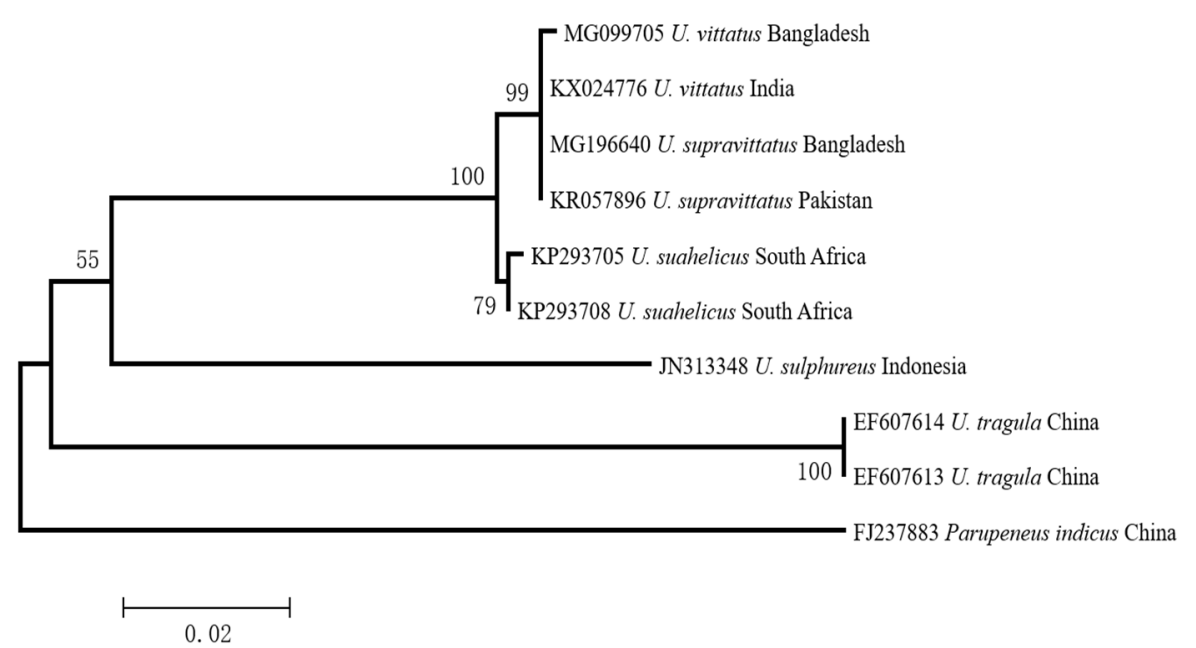

Fig. 3. Neighbor-joining tree constructed using the K2P model for COI gene sequences of six species of Upeneus with Parupeneus indicus as the outgroup. 
Table 6. Mean interspecies genetic distances (K2P) between six species of family Mullidae.

\begin{tabular}{lccccc}
\hline & U. vittatus & U. supravittatus & U. suahelicus & U. sulphureus & U. tragula \\
\hline U. vittatus & & & & & \\
U. supravittatus & 0.002 & & & & \\
U. suahelicus & 0.009 & 0.008 & & & \\
U. sulphureus & 0.118 & 0.116 & 0.115 & 0.159 & 0.198 \\
U. tragula & 0.158 & 0.156 & 0.152 & 0.183 & \\
Parupeneus indicus & 0.163 & 0.161 & 0.155 & & \\
\hline
\end{tabular}

There are a few reports on the occurrence of Upeneus species in Bangladesh. For example, only three species of this genus, U. sulphureus (Tomascik 1997), $U$. sundaicus and $U$. tragula (Rahman et al. 2009) are reported in Bangladesh waters based on their identification only on external morphological characters. However, misidentifications are known to result from damaged or poor specimens and ambiguous morphological features (Arai and Wong 2016). Morphological characters are ineffective to distinguish species at some stages of development (Ward et al. 2009). Several authors have suggested that molecular genetic analyses are necessary for precise species confirmation (Arai et al. 2015, Arai and Wong 2016, Kadir et al. 2017). However, on the basis of morphological characters and DNA barcoding, U. vittatus and U. supravittatus were newly recorded in Bangladesh. Photographs, counts and measurements were taken for morphological characters, then comparison of the present study was done with the reports of Uiblein and Heemstra (2010), Kuiter and Tonozuka (2001) and FAO (1983a,b,c). Even though some do not precisely fall into the range reported by others, due to differences in growth rate and sampling size for some of the characters that either overlap or span the range. The K2P distance between $U$. vittatus and $U$. supravittatus is $0.2 \%$. This is lower than threshold of species delimitation $3.5 \%$ (Ward et al. 2005, 2009). This may be due to lower genetic diversity between closely related and apparently morphologically similar species of the genus Upeneus such as $U$. supravittatus and $U$. suahelicus have only $0.8 \%$ genetic divergence (Uiblein and Gouws 2015) that is also lower than threshold of species delimitation 3.5\% (Ward et al. 2005, 2009).For more confirmation need further study such as Kruck et al. 2013 suggested that when CO1 revealed low interspecific variation which is insufficient for genetic distance-based species identification and mismatch among morphological identifications then multi-gene spot test approach and efficient markers (recombination activating gene 2 in combination with NADH dehydrogenase 2 and ATP synthase) may help identifying problematic fish species. 


\section{Conclusion}

For the first time in Bangladesh Upeneus vittatus and U. supravittatus were recorded based on both morphomeristics and DNA barcoding. The morphomeristics descriptions are compatible with descriptions of these species given by Zoologists. Moreover, these two species and other three previous Bangladeshi Upeneus species can be distinguished from each other by combination of characters like body stripe, body color, spot, stripe or patch on dorsal fin, bar on caudal fin, lateral line scales and scales above and below the lateral line. Although $U$. vittatus and $U$. supravittatus have low genetic variation but significant difference from other species of the same genus that were also confirmed from comparative COI sequence analysis of the present study with reference sequences. Therefore, $U$. vittatus and $U$. supravittatus are valid species at the genetic level.

\section{Acknowledgements}

Authors are grateful to the authority of SAU-KIOST collaborative project "Exploration of Coastal and Marine Biological Resources of Bangladesh" and Ministry of National Science and Technology for financial support in molecular part of this research work and local people of St. Martin's Island for collection of fish.

\section{References}

Arai, T., T.C. Chin, K.O. Kwong, and M.N. Siti Azizah. 2015. Occurrence of the tropical eels, Anguillabengalensis bengalensis and A. bicolor bicolor in Peninsular Malaysia, Malaysia and implications for the eel taxonomy. Mar. Biodiver. Reco. 8: e28. https://doi.org/ $10.1017 /$ S 1755267215000950

Arai, T, and L.L. Wong. 2016. Validation of the occurrence of the tropical eels, Anguilla bengalensis bengalensis and A. bicolor bicolor at Langkawi Island in Peninsular Malaysia, Malaysia. Tropi. Ecol. 57: 23-31.

FAO, 1983a. FAO species identification sheets, Mullidae. Fishing area 51 (West Indian Ocean).1654 pp. ftp://ftp.fao.org/docrep/fao/009/y4162e/y4162e32.pdf

FAO,1983b. FAO species identification sheets, Mullidae. Fishing area 51 (West Indian Ocean).3175 pp. ftp://ftp.fao.org/docrep/fao/009/y0770e/y0770e39.pdf

FAO, 1983c. FAO species identification sheets, Mullidae. Fishing area 51 (West Indian Ocean). ftp://ftp.fao.org/docrep/fao/009/ad468e/AD468eIF.pdf

Fischer, W., I. Sousa, and C. Silva.1990. Sheets FAO species identification of fishing activities. Field guide of commercial marine species. Roma, FAO. 424 pp.

Hebert, P.D.N, A. Cywinska, and S.L. Ball.2003. Biological identifications through DNA barcodes. Proc. R. Soc. Lond. B. 270: 313-321.

Ivanova, N.V., T.S. Zemlak, and R.H. Hanner, 2007. Universal primer cocktails for fish DNA barcoding. Mol Eco N. 4(7): 544-548. 
Kadir. A., S.R., M.H.F. Abdul Rasid, K.O. Kwong, L.L. Wong, and T. Arai. 2017. Occurrence and the ecological implication of a tropical anguillid eel Anguilla marmorata from peninsular Malaysia. ZooKeys.695: 103-110. https://doi.org/10.3897/zookeys.695.13298

Kimura, M.1980.A simple method for estimating evolutionary rates of base substitutions through comparative studies of nucleotide sequences. J. Mol. Evo. 16:111-120.

Kruck, N.C., I.R. Tibbetts, R. D. Ward, J.W. Johnson, W.K.W. Loh, and J.R. Ovenden. 2013. Multi-gene barcoding to discriminate sibling species within a morphologically difficult fish genus (Sillago). Fishe. Res. 143: 39-46.

Kuiter, R.H, and T. Tonozuka. 2001. Pictorial guide to Indonesian reef fishes. Part 1. EelsSnappers, Muraenidae - Lutjanidae. Zoone. Aus. 1-302 pp.

Lewis, A.D, and C.K. Pring.1986. Freshwater and brackish water fish and fisheries of Fiji. 3859 p. In: Reports and papers presented at the Indo-Pacific Fishery Commission Expert Consultation on inland fisheries of the larger Indo-Pacific islands. Bangkok, Thailand, 4-6 August 1986. FAO Fish. Rep. (371) Suppl.:258 p. (eds. Petr T)

Lieske, E, and R. Myers. 1994. Collins Pocket Guide. Coral reef fishes. Indo-Pacific \& Caribbean including the Red Sea. Haper Collins Publishers. 400 pp.

Mundy, B.C.2005.Checklist of the fishes of the Hawaiian Archipelago. Bishop Museum Bulletins in Zoology. Bishop Mus. Bull. Zool. 6: 1-704.

Rahman, A.K.A., S.M.H. Kabir, M. Ahmed, A.T.A. Ahmed, Z.U. Ahmed, Z.N.T. Begum, M.A. Hasan, and M. Khondker. (eds.) 2009. Encyclopedia of Flora and Fauna of Bangladesh, vol. 24 Marine Fishes. Asiatic Society of Bangladesh, Dhaka. 24: 276-279.

Saitou, N, and M. Nei. 1987.The neighbor-joining method: A new method for reconstructing phylogenetic trees. Mol Biol Evol. 4: 406-425.

Schultz L.P, and collaborators. 1960. Fishes of the Marshall and Marianas Islands. Bull. US Natl. Mus. vol. 2. 202: ix +438 pp.

Sea-Ex (http://www.sea-ex.com/fishphotos/goatfish.htm)

Sousa, M. I, and M. Dias. 1981. Catalog Fish Mozambique - South Zone Fishing Development Institute, Maputo. $121 \mathrm{pp}$.

Tamura, K., G. Stecher, and D. Peterson. 2013. MEGA6: Molecular Evolutionary Genetics Analysis Version 6.0. Mol. Biol. Evol. 30: 2725-2729.

Tomascik, T.1997. Management plan for coral resources of Narikel Jinjira (St. Martin's Island), national conservation strategy implementation project-1, Ministry of Environment and Forest, Government of Bangladesh. 126 pp.

Uiblein, F, and P.C. Heemstra.2010.A taxonomic review of the Western Indian Ocean goatfishes of the genus Upeneus (Family Mullidae), with descriptions of four new species. Smithiana.11: 35-71.

Uiblein, F, and P.C. Heemstra. 2011. Description of a new goat fish species, Upeneus seychellensis sp. nov. (Mullidae) from the seychelles Bank with remarks on Upeneus guttatus geographic variation and a key for all Western Indian Ocean Upeneus species. Mar. Biol. Res.7: 637-650. 
Uiblein, F, and G. Gouws. 2015. Distinction and relatedness -Taxonomic and genetic studies reveal a new species group of goatfishes (Upeneus; Mullidae), Mar. Biol. Res. 11:10, 10211042, DOI: 10.1080/17451000.2015.1064963

Ward, R.D., T.S. Zemlak, and B.H. Innes. 2005. Barcoding Australia's fish species. Philos. Trans. R. Soc. of Lond B. 360: 1847-1857.

Ward, R.D., R. Hanner, and P.D.N. Hebert. 2009. The campaign to DNA barcode all fishes, FISH-BOL. J. Fish Biol. 74: 329-356.

Ward, R.D. 2012. FISH-BOL, a case study for DNA barcodes. Methods Mol. Biol. 858: 423-439.

Yamashita, Y., D. Golani, andH. Motomura. 2011.A new species of Upeneus (Perciformes: Mullidae) from southern Japan. Zootaxa. 3107: 47-58.

(Revised copy received 25.07.2019) 